\title{
Directions and tendencies of migration of the population into urban areas of the Republic of Srpska \\ Tanja Mišlicki Tomić ${ }^{*}$ and Vesna Rajcevic ${ }^{* *}$
}

A R T I C E IN F O A B S T A C T

Received:

March 31,

2021.

Received in revised form: August 24, 2021.

Accepted:

August 30, 2021.

Published online:

September 07, 2021
This paper covers internal migrations in the Republic of Srpska, in the period 2007-2015 and their impact to urban and peri-urban development of urban areas of the Republic. Migration directions show a continuity of permanent abandonment of rural areas and settlement of urban and periurban areas of the Republic, also including the migrations (immigration) from the Federation of Bosnia and Herzegovina. The scope of migrations has the trend of decrease as result of decrease in the rural population of the Republic of Srpska and its aging. Urban centres of the northern part of the Republic of Srpska (Banja Luka, Doboj, Bijeljina, Prijedor and Gradiška) have the largest scope of immigration, due to a number of attractive factors. In the southern part of the Republic, in the sub-Mediterranean area, the City of Trebinje is the main immigration area for the population of eastern Herzegovina, but also, more and more, for the population of the rest of the Republic of Srpska, as well for the wider regional environment. Spatial scope of research consists of eight cities in the Republic of Srpska, which defined the status of the city in the period from 1995 to 2019. Those cities are: Banjaluka, Bijeljina, Prijedor, Gradiška, Doboj, Istočno Sarajevo, Zvornik and Trebinje.

The specificities in the territorial organization of the Republic of Srpska are the result of complex socio-political processes and the formation of the entity line of demarcation in post-war period (1992-1995), between the Federation of Bosnia and Herzegovina and the Republic of Srpska. Given the physiognomy of space and developmental processes, the Republic of Srpska has complex settlement function.

In four urban areas, Istočno Sarajevo, Doboj, Zvornik and Trebinje, the settlements are divided by the entity line, which caused the migrations. In 2014, population migration was also affected by administrative separation of the municipality of Stanari from the Doboj city area. Due to the above mentioned, compared to other cities of the Republic, Doboj has the highest negative values of the migration balance in the observed period (2007-2016). Statistical data from the Federal Bureau of Statistics of $\mathrm{BiH}$ and the Republic Institute of the Republic of Srpska were used in research related to migrations, as well as other relevant statistical material produced in the period from 1991 to 2016. The key demographic indicators, internal migrations, immigration and emigration and migration balance were taken into consideration. In order to compare the research areas, data were prepared on the basis of demographic indicators. Conclusions on spatial integration of migration, as well as its direction, have been drawn based on internal migration, spatial distribution of population and change in number of inhabitants in urban and suburban settlements.

Key words: The Republic of Srpska, migrations, suburbanization, migration balance.

To cite this article: Mišlicki Tomić, T. and Rajcevic, V. (2021). Directions and Tendencies of Migration of the Population into Urban Areas of the Republic of Srpska. Urbana, 22, 9-25. Retrieved from http://www.urbanauapp.org/ https://doi.org/10.47785/urbana.2.2021

\footnotetext{
${ }^{*} \mathrm{PhD}$, Assistant Professor, University of Banja Luka, Faculty of Natural Sciences and Mathematics, tanja.mislicki-tomic@.pmf.unibl.org

${ }^{* *}$ Associate Professor, University of Banja Luka, Faculty of Natural Sciences and Mathematics, 


\section{Introduction}

The European Union officially recognized Bosnia and Herzegovina as a sovereign state on 6 April 1992, and the next day the United States did the same. Since then, a three-and-a-half-year war has been fought in the geospace of Bosnia and Herzegovina. The beginning of the war was based on the conflict between Serbs and joint Muslim-Croat forces, and after the collapse of the coalition in 1993, the war gained the most typical features of ethnic-religious and civil war. The provisions of the Peace Agreement (better known as the Dayton Agreement, of 21 November 1995) constituted Bosnia and Herzegovina as a state composed of two entities: Federation of Bosnia and Herzegovina and the Republic of Srpska. Both entities have been given competencies that independent political-territorial subjects have. However, the Agreement did not resolve the issue of the inter-entity border in the Brčko area. The disputed issue was resolved by an arbitral award of 5 March 1999, by the Chairman arbitrator, which reads the entire area of the municipality of Brčko, from the time of the former $\mathrm{SR} \mathrm{BiH}$, as a district. Thus, Bosnia and Herzegovina was constituted as a state of two entities and the Brčko District (Nodal-functional regionalization of the Republic of Srpska, 2008, p. 3-5).

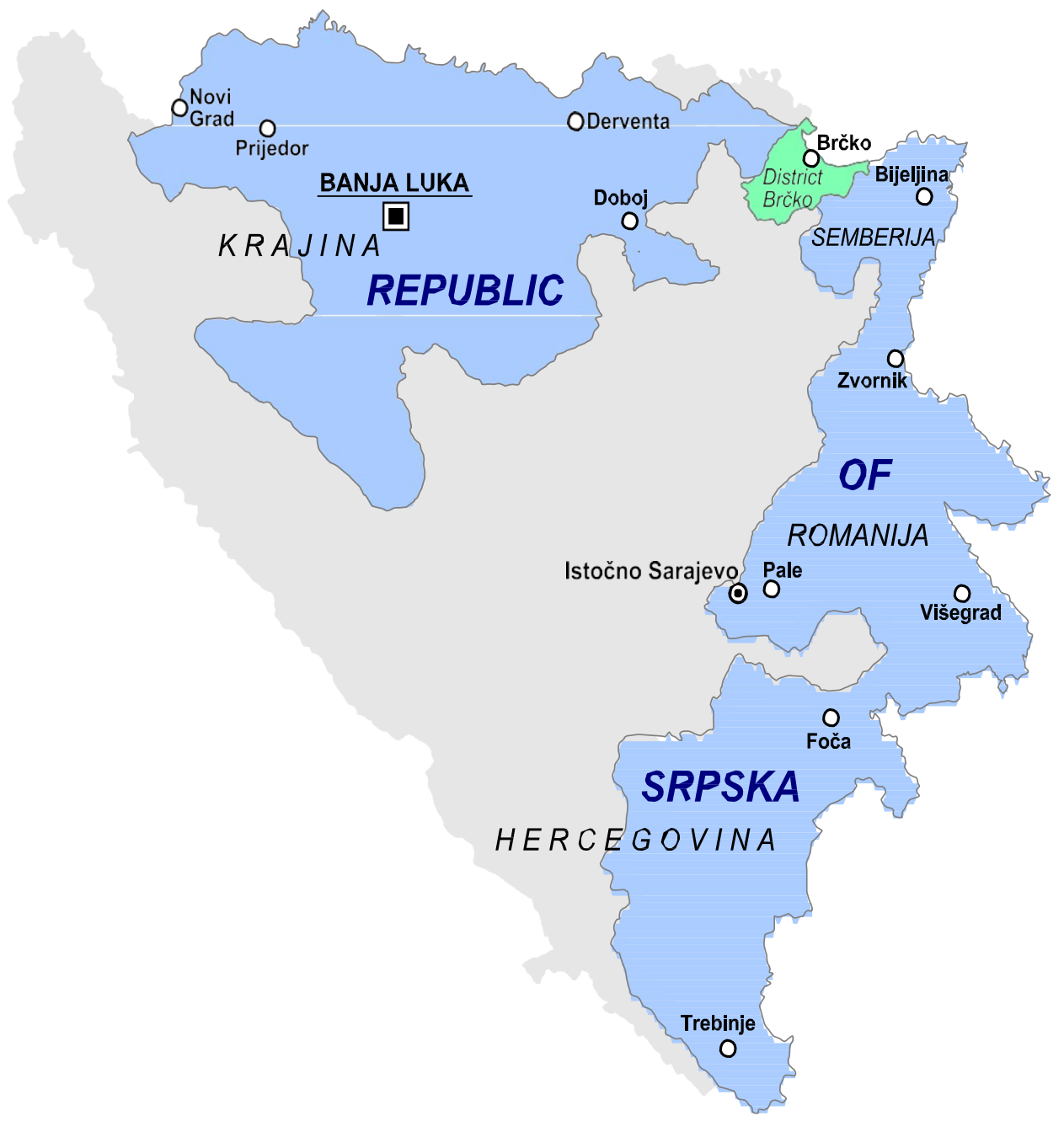

Fig.1 The position of the Republic of Srpska in Bosnia and Herzegovina.

Source: $\quad$ https://commons.wikimedia.org/w/index.php?curid=6393512 
The Republic of Srpska, with its position in Bosnia and Herzegovina, covers 24,856 $\mathrm{km} 2$ or $49 \%$ of the territory of $\mathrm{BiH}$. The territory stretches from the Una River in the west to the Drina in the east in the length of $250 \mathrm{~km}$, and in the north-south direction from the Sava River to the village of Grab in the municipality of Trebinje in the length of $270 \mathrm{~km}$. This area is characterized by a specific shape with an elongated state territory in the east-west and northsouth directions. The Republic of Srpska borders Serbia, Montenegro, Croatia and the Federation of $\mathrm{BiH}$. The total length of the Republic of Srpska border is about 2,170 km long, of which $1,080 \mathrm{~km}$ is international. The inter-entity delimitation sector is very long due to the meandering of the border, about 1,090 km. The border of the Republic of Srpska is also the result of a compromise and agreement on the replacement of parts of the territories between the two entities, such as the village of Hasani, and the areas of Bosanska Krupa, Doboj, Tuzla, Bijeljina, Zvornik, Nevesinje, Mostar and Prijedor. (Same, 2008, p. 7).

According to the estimates of the Republic Institute of Statistics, the Republic of Srpska had 1,157,516 inhabitants in 2016, which is 13,663 inhabitants less than in mid-2013. The estimate is based on the results of the 2013 census and the ratio of the number of live births, deaths, immigrants, and emigrants in internal migration in the period 2013-2016. The estimated number of inhabitants should be taken with a pinch of salt because it includes only the closed population, i.e., does not include the mechanical component of external migrations. Given the negative tendencies of the external migration balance, most demographers believe that the number of resident populations in 2016 is even lower than official statistical estimates. (Marinković, Majić, 2018, p. 47-48)

The Republic of Srpska is characterized by negative natural population movements, and the poor biodynamics and prospects of demographic development are negatively affected by the changed structures of the population, especially age structure, but also other. To such unfavourable demographic trends of the population, we should also add the increasingly dynamic movement of the working-age population and university degree population towards other countries, mostly for socio-economic reasons.

With the disintegration of the SFRY and in the post-war period (1992-1996), the process of emigration caused a strong depopulation of rural areas, but also a decrease in the number of inhabitants in urban areas. Migration processes have started to play a key role in the spatial distribution of the population. The population is increasingly leaving less developed rural areas, and areas divided by the entity line of demarcation, and moving towards more functionally developed centres. Processes of suburbanization are intensified by socio-economic changes. Spatial expansion of urban and peri-urban settlements forms complex urban systems with pronounced migration.

The directions of migration in the cities of the Republic of Srpska show the continuity of permanent abandonment of rural areas and settlement of urban areas.

According to the Census from 1991, in rural settlements of the Republic of Srpska lived 933,912 inhabitants and 599,634 inhabitants in 2013, or 36\% inhabitants less.

According to the Census from 1991, a third of the population lived in the cities of the Republic (45.1\%), while in the period from 1991 to 2013, that number increased to half $(52.9 \%)$. 
In the period from 2007 to $2016,63,046$ persons immigrated to the cities of the Republic of Srpska, of which 58.5\% from the surrounding rural areas, and 35\% from $\mathrm{FBiH}$ and 3.5\% from Brčko District.

In the period from 1991 to 2013, the population showed a tendency of faster growth in the gravitational spheres of more developed cities, while the population number decreased in settlements which are far from city centres and main traffic communications.

\section{Bibliography review}

The essential features of the territorial organization of the Republic of Srpska arise from the Dayton Agreement, verified in Paris in 1995, according to which the Republic of Srpska is defined as the entity within the state of Bosnia and Herzegovina.

In the period from 1995 to 2019, spatial and functional organization of the Republic of Srpska was changing. Upon its establishment, the Republic of Srpska had two urban settlements, Banja Luka and Istočno Sarajevo, and in 2019 there are eight urban settlements. In the period from 1995 to 2019, the relevant laws defining the spatial and functional organization are taken into consideration (The Law on Territorial Organization and Local Self-Government of the Republic of Srpska, the Law on the Cities in the Republic of Srpska, the Law on the Establishment of the Municipality of Stanari, etc.)

The complexity of demographic changes in the above-mentioned period were reviewed on the basis of the Census from 1991 and 2013, published by the Federal Bureau of Statistics of $\mathrm{BiH}$ and the Institute of Statistics of the Republic of Srpska, as well as on the basis of other relevant statistic material (newsletters, yearbooks, demographic review, etc.).

These issues are analysed in numerous scientific papers published in scientific bulletins (Gnjato, 2011; Gnjato, 2013; Šabić, 2016), as well as in scientific publications (Špirić, Marijanac, 1999; Pašalić and others 2006; Marijanac, 2012) and monograph (Marinković 2005; Mandić 2013; Živković 2016; Marinković, Majić, 2018).

These issues have also been processed in many scientific papers in the surrounding countries, Croatia (Bašić, 2005; Klepić Bogadi, 2008), Serbia (Nikitović V., 2015; Bobić, Anđelković, Kokotović, 2016), which encountered similar socio-economic changes after disintegration of Yugoslavia

\section{Methods and spatial extent}

The time extent of migration research includes the period from 2007 to 2016. Spatial scope of research consists of eight cities in the Republic of Srpska, which defined the status of the city in the period from 1995 to 2019. Those cities are: Banjaluka, Bijeljina, Prijedor, Gradiška, Doboj, Istočno Sarajevo, Zvornik and Trebinje.

Cities consist of city centres and municipalities.

The specificities in the territorial organization of the Republic of Srpska are the result of complex socio-political processes and the formation of the entity line of demarcation in postwar period (1992-1995), between the Federation of Bosnia and Herzegovina and the Republic of Srpska. Given the physiognomy of space and developmental processes, the Republic of Srpska has complex settlement function.

In the period from 1996 to 2012, the Republic of Srpska unites the two cities in administrative and functional terms, Banjaluka and Istočno Sarajevo and 61 municipality (the 
Law on Territorial Organization and Local Self-Government of the Republic of Srpska, Official Gazette of the Republic of Srpska, number: 11/94, 6/95, 26/95, 15/96, 17/96, 19/96 and 6/97). In the period from 2012 to 2014, four settlements got the status of the city: Bijeljina, Doboj, Prijedor and Trebinje (The Law on Territorial Organization and Local Self-Government of the Republic of Srpska, Official Gazette of the Republic of Srpska, number: 103/05, 69/09, 70/12). And in the period from 2014 to 2019, two more settlements, Zvornik and Gradiška, got the status of the city (the Law on the City of Zvornik, Official Gazette of the Republic of Srpska, number: 83/14, 106/15 and the Law on the City of Gradiska, Official Gazette of the Republic of Srpska, number: 26/19). In 2019, the settlement system of the Republic of Srpska consists of eight cities and 56 municipalities.

In four urban areas, Istočno Sarajevo, Doboj, Zvornik and Trebinje, the settlements are divided by the entity line, which caused the migrations.

The largest number of settlements which are divided by the entity line are located in city area of Istocno Sarajevo, the total of 43 settlements.

From the pre-war large area that made Sarajevo, independent municipalities emerged in the Federation of Bosnia and Herzegovina (Hadžići, Ilidža, Ilijaš and Vogošća), i.e. (Pale) in the Republic of Srpska. The mountain-rural municipality of Trnovo mostly belonged to the Federation of $\mathrm{BiH}$, while a smaller part belonged to the Republic of Srpska. The city municipalities of Sarajevo are divided so that the municipalities of Istočna Ilidža (Kasindo), Istočni Stari Grad (Hreša), Istočno Novo Sarajevo (Lukavica) in the Republic of Srpska are formed from parts of the municipalities of Ilidža, Stari Grad and Novo Sarajevo. Continuing the administrative-political tradition of SFR Yugoslavia, post-war Sarajevo was organized as a city community of municipalities. In this regard, the City of Sarajevo consists of the municipalities of Ilidža, Stari Grad, Novi Grad and Novo Sarajevo. Opposite to the City of Sarajevo, which is the seat of the Sarajevo Canton, the capital of the Federation of $\mathrm{BiH}$ and the entire state, the municipalities of Istočna Ilidža, Istočno Novo Sarajevo, Istočni Stari Grad, Pale, Sokolac and Trnovo created a city community, i.e. the City of Istočno Sarajevo. Although the headquarters of all entity institutions of the Republic of Srpska are located in Banja Luka, Istočno Sarajevo was held as the de jure capital of that entity (Raos, 2010, p. 8).

The city was formed in post-war period from 1992 to 1995. It consists of six municipalities: Istočno Novo Sarajevo, Istočna Ilidža, Pale, Sokolac, Trnovo and Istočni Stari Grad and 216 populated places (the Law on the City of Istočno Sarajevo, Official Gazette of the Republic of Srpska, number: 25/93, 8/96, 27/96 and 33/97, 85/03, 01/05).

In the case of the city, i.e. the pre-war municipality of Doboj, by delimitation, the largest part of the municipality of Doboj belonged to the Republic of Srpska, while the peripheral rural parts belonged to the Federatio of $\mathrm{BiH}$. Since these settlements are not territorially interconnected, two municipalities, Doboj Jug and Doboj Istok, were created (Raos, 2010, p.7).

In the period from 2012 to 2014, the municipality of Doboj received the status of a city (Law on Territorial Organization and Local Self-Government of the Republic of Srpska, Official Gazette of the Republic of Srpska, number: 103/05, 69/09, 70/12).

In 2014, population migration was also affected by administrative separation of the municipality of Stanari from the Doboj city area (the Law on the Establishment of the Municipality of Stanari, Official Gazette of the Republic of Srpska, number: 83/14). Due to the 
above mentioned, compared to other cities of the Republic, Doboj has the highest negative values of the migration balance in the observed period (2007-2016).

In the 2013 census, according to demographic size, the largest cities in Republic of Srpska are: Banja Luka (180,053 inhabitants) and Bijeljina (103,874 inhabitants). Other cities in the Republic of Srpska have a smaller population: Prijedor (80,916 inhabitants), Doboj (68,514 inhabitants), Istočno Sarajevo (59,916 inhabitants) and Zvornik (54,407 inhabitants).

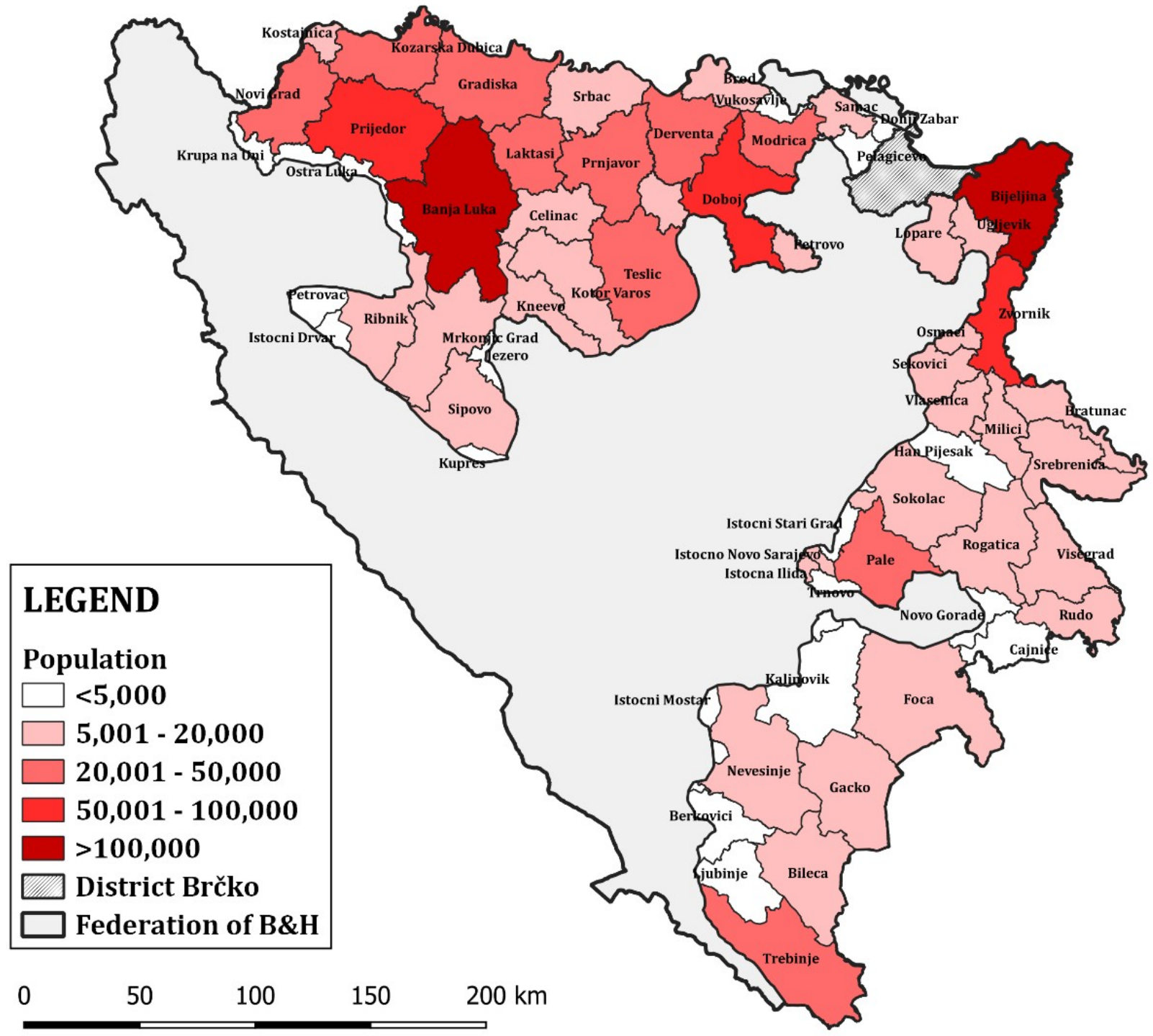

Fig.2 P o p u lat i o $\mathrm{n}$ in cities and municipalities of the Republic of Srpska according to the 2013 census.

Source: Marinković, Majić (2018, Page 53).

Statistic data from the Federal Bureau of Statistics of BiH and the Republic Institute of the Republic of Srpska were used in research related to migrations, as well as other relevant statistical material produced in the period from 1991 to 2016. The key demographic indicators, internal migrations, immigration and emigration and migration balance were taken into consideration. To compare the research areas, data were prepared on the basis of demographic indicators. Conclusions on spatial integration of migration, as well as its direction, have been drawn based on internal migration, spatial distribution of population and change in number of inhabitants in urban and suburban settlements. 
Regular daily migration or weekly migration, which is the departure from the place of residence to another place because of the work, is not taken into account, because the statistics of the Republic of Srpska do not have a systematic database on this type of population movement.

\section{International migrations in the cities of the Republic of Srpska}

In the Republic of Srpska, within its current borders, there were 1,570,165 inhabitants in the 1991 census (Marinković, Vranješ, 2013, p. 38), and according to the final results of the 2013 census, there were 1,170,342 inhabitants (Marinković, Majić, 2018, p. 49). The Republic of Srpska is facing problems of demographic aging and depopulation. In the period from 1991 to 2013, according to population census from 1991 and 2013, population of the Republic of Srpska decreased for 399,823 or $25.5 \%$. A significantly higher proportion of the elderly is observed compared to the young population (Marinković, Majić, 2018, p. 49). According to census from 2013, there are 625,115 inhabitants in the cities, or $52.9 \%$ population of the Republic. In 2013, compared to 1991, the decrease in the population of Republic of Srpska is visible in the cities as well. In the period from 1991 to 2013, population in cities decreased to 77,010 persons as follows: in Prijedor and Doboj for $28 \%$, in Gradiška for 18\%, in Zvornik for $17.5 \%$, in Banjaluka for $7.7 \%$ and in Trebinje for $2.9 \%$. In the same period, only two cities recorded increase in population number, Istočno Sarajevo for $21.6 \%$ and Bijeljina $7.3 \%$ (Table 1$)$.

\begin{tabular}{|c|c|c|c|c|c|c|c|}
\hline \multirow{3}{*}{$\begin{array}{c}\text { Cities in the } \\
\text { Republic of } \\
\text { Srpska }\end{array}$} & \multicolumn{6}{|c|}{ Number of inhabitants } & \multirow{3}{*}{$\begin{array}{c}\text { Inter-census } \\
\text { change } \\
1991 / 2013 \\
\text { Urban area }\end{array}$} \\
\hline & \multicolumn{3}{|c|}{1991} & \multicolumn{3}{|c|}{2013} & \\
\hline & $\begin{array}{l}\text { Urban } \\
\text { area }^{1}\end{array}$ & $\begin{array}{c}\text { Close } \\
\text { urban area }\end{array}$ & $\begin{array}{c}\text { Marginal } \\
\text { zone of } \\
\text { the urban } \\
\text { area }\end{array}$ & $\begin{array}{c}\text { Urban } \\
\text { area }\end{array}$ & $\begin{array}{c}\text { Close } \\
\text { urban area }\end{array}$ & $\begin{array}{l}\text { Marginal } \\
\text { zone of the } \\
\text { urban area }\end{array}$ & \\
\hline Banjaluka & 195,139 & 142,644 & 52,495 & 180,053 & 135,059 & 44,994 & $-15,086$ \\
\hline Bijeljina & 96,796 & 36,187 & 60,609 & 103,874 & 41,121 & 62,753 & 7,078 \\
\hline Gradiška & 60,062 & 16,989 & 43,073 & 49,196 & 13,691 & 35,505 & $-10,866$ \\
\hline Prijedor & 112,470 & 34,627 & 77,843 & 80,916 & 27,970 & 52,946 & $-31,554$ \\
\hline Doboj & 95,713 & 27,579 & 68,134 & 68,514 & 24,349 & 44,165 & $-27,199$ \\
\hline Doboj* & 83,213 & 27,579 & 55,634 & 61,556 & 24,349 & 37,207 & $-21,657$ \\
\hline I. Sarajevo** & 46,979 & 22,353 & 24,626 & 59,916 & 37,031 & 22,885 & 12,937 \\
\hline Trebinje & 29,094 & 21,810 & 7,284 & 28,239 & 22,987 & 5,252 & -855 \\
\hline Zvornik & 65,872 & 14,584 & 51,288 & 54,407 & 11,082 & 43,325 & $-11,465$ \\
\hline Total & 702,125 & 316,773 & 385,352 & 625,115 & 313,290 & 311,825 & $-77,010$ \\
\hline
\end{tabular}

Table 1 Number of inhabitants and inter-census change in the cities of the Republic of Srpska, in the period from 1991 to 2013.

Source: (Marinković, Majić,2018, Page 308-309); Census of Population, Households, Dwellings and Farms 1991, Republic Institute of Statistics of the Federal Republic of Bosnia and Herzegovina, Sarajevo, 1991; Census of Population, Households, Dwellings in the Republic of Srpska in 2013, Republic Institute of Statistics of the Republic of Srpska, Banja Luka, 2017.

1 The urban area consists of two macro-units: the close urban area and the marginal zone of the urban area. All lands within the close urban area are construction land. The marginal zone of the urban area includes construction and agricultural land.

* Doboj - Data for the City of Doboj do not include data for the municipality of Stanari Istočno

** Sarajevo - Data for the City of Istočno Sarajevo include data for the municipalities of Istočno Novo Sarajevo, Istočna Ilidža, Pale, Sokolac, Tnovo and Istočni Stari Grad. 


\begin{tabular}{|c|c|c|c|}
\hline $\begin{array}{c}\text { Cities in the } \\
\text { Republic of } \\
\text { Srpska }\end{array}$ & Indigenous population & \multicolumn{2}{|c|}{ Immigrant population } \\
\cline { 3 - 4 } & & Total & from BiH \\
\hline Banjaluka & 39.3 & 60.7 & 74.6 \\
\hline Bijeljina & 32.6 & 67.4 & 79.4 \\
\hline Gradiska & 34.8 & 65.2 & 62.3 \\
\hline Prijedor & 29.0 & 71.0 & 80.7 \\
\hline Doboj & 35.9 & 64.1 & 92.4 \\
\hline I. Sarajevo** & 21.1 & 78.8 & 73.6 \\
\hline Trebinje & 40.5 & 59.5 & 82.2 \\
\hline Zvornik & 31.1 & 68.9 & 76.2 \\
\hline Total in RS & 35.3 & 64.7 & \\
\hline
\end{tabular}

Table 2 Share of the indigenous and immigrant population, in accordance with the scope of internal migrations in the cities of the Republic of Srpska, in the year 2013, in \%.

Source: (Marinković, Majić,2018, Page 318-319)

* Doboj. Data for the City of Doboj include data for the municipality of Stanari.

** Istočno Sarajevo- Data for the City of Istočno Sarajevo include data for the municipalities of Istočno Novo Sarajevo, Istočna Ilidža, Pale, Sokolac, Tnovo and Istočni Stari Grad.

In the post-war period (1996-2016), the negative rate of natural growth conditioned the process of natural depopulation in which the population of the Republic of Srpska decreased by about $4 \%$. In the past 20 years, a total of 234,535 children were born, 280,381 inhabitants died at the same time, so only on the basis of natural increase, the Republic of Srpska reduce its population by -45,846 inhabitants. (Marinković, Majić, 2018, p. 141).

The rate of natural depopulation in the cities of the Republic of Srpska is more pronounced if the cumulative values of natural increase are considered. In the period 19962016, the largest demographic losses based on natural change were registered in four cities of the Republic of Srpska: Prijedor (-6,688), Bijeljina $(-3,650)$, Gradiška $(-3,059)$ and Doboj (2,902) (Same, 2018, p. 143).

Unfavourable demographic trends directly affected the aging population, but also the reduction of the working age population. In the 2013 census, compared to 1991, the number of young populations decreased from $22 \%$ to $14 \%$, mature from $70 \%$ to $68 \%$, while the number of old populations increased from $8 \%$ to $17 \%$. Negative natural movements are recorded in cities (Marinković, Majić, 2018, p. 180).

\begin{tabular}{|c|c|c|c|c|c|}
\hline $\begin{array}{c}\text { Cities in the } \\
\text { Republic of } \\
\text { Srpska }\end{array}$ & $\begin{array}{c}\text { Number of } \\
\text { inhabitants } \\
\mathbf{( 1 9 9 1 / 2 0 1 3 )} \\
\text { Difference }\end{array}$ & $\begin{array}{c}\text { Natural } \\
\text { increment } \\
\mathbf{( 2 0 0 0 / 2 0 1 6 )} \\
\text { difference }\end{array}$ & $\begin{array}{c}\text { Absolute } \\
\text { natural change } \\
\mathbf{( 1 9 9 6 / 2 0 1 6 )}\end{array}$ & $\begin{array}{c}\text { Average } \\
\text { age } \\
\mathbf{( 2 0 1 3 )}\end{array}$ & $\begin{array}{c}\text { Migration } \\
\text { balance } \\
\mathbf{( 2 0 0 7 - 2 0 1 6 )}\end{array}$ \\
\hline Banjaluka & $-15,086$ & -184 & 4,138 & 40.4 & 9,325 \\
\hline Bijeljina & 7,078 & -587 & $-3,650$ & 41.2 & 6,195 \\
\hline Gradiska & $-10,866$ & -391 & $-3,059$ & 42.6 & 78 \\
\hline Prijedor & $-31,554$ & -641 & $-6,688$ & 42.3 & 237 \\
\hline Doboj & $-27,199$ & -352 & $-2,998$ & 42.1 & $-5,659$ \\
\hline I. Sarajevo & 12,937 & -441 & $-4,262$ & 42.7 & 3,969 \\
\hline Trebinje & -855 & -109 & -628 & 42.2 & 632 \\
\hline Zvornik & $-11,465$ & -392 & 1,321 & 39.3 & $-1,514$ \\
\hline
\end{tabular}

Table 3 Absolute values and changes in the natural movement of population in cities of the Republic of Srpska, in the period from 1996 to 2016.

Source: (Marinković,Majić,2018, Page 316-317); Census of Population, Households, Dwellings and Farms 1991, Republic Institute of Statistics of the Federal Republic of Bosnia and Herzegovina, Sarajevo, 1991; Census of Population, Households, Dwellings in the Republic of Srpska in 2013, Republic Institute of Statistics of the Republic of Srpska, Banja Luka, 2017, Demographic statistics 4, 10, 11, 15 and 20, Republic Institute of Statistics of the Republic of Srpska, Statistical newsletters, 2017. 


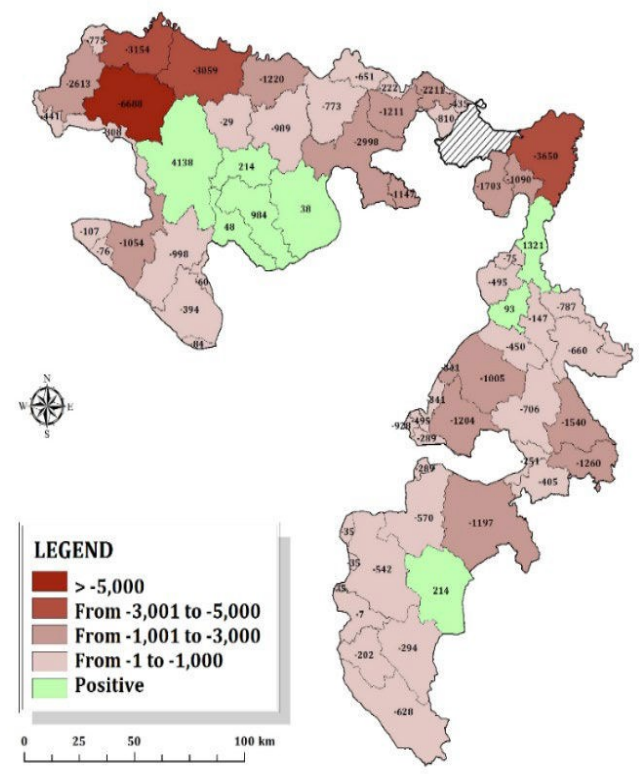

Fig.3 C u m u lat i v e natural increase in cities and municipalities of the Republic of Srpska in the period 19962016.

Source: Marinković, Majić (2018, Page 177).

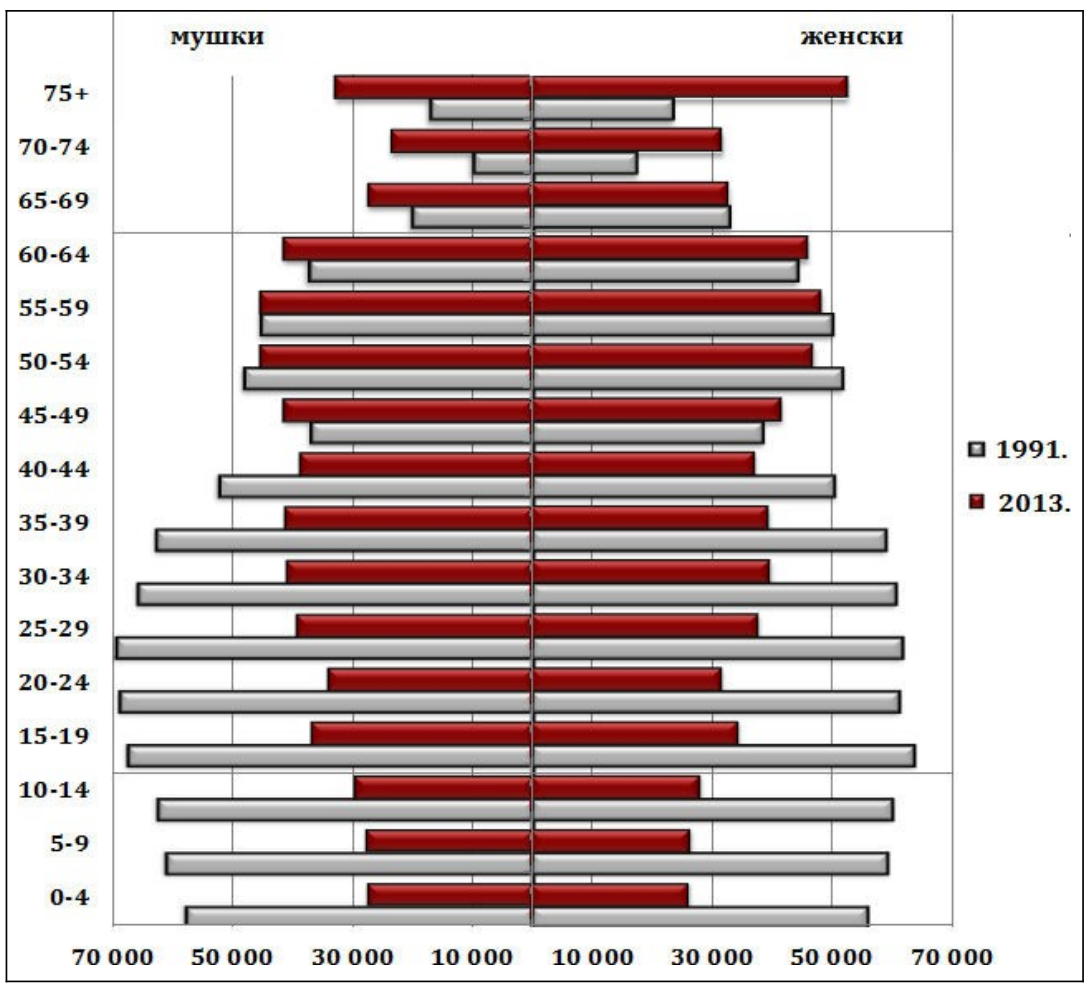

Fig.4 Age and sex structure of the population of the Republic Srpska in the 1991 and 2013 censuses. Source: (Marinković, Majić,2018, Page 179). 
In the period from 2007 to 2016, negative migration balance is recorded in Doboj ($5,659)$ and Zvornik $(-1.514)$, and the highest positive migration balance is recorded in Banja Luka $(9,325)$, Bijeljina $(6,195)$ and Istočno Sarajevo $(3,969)$ (Table 3).

The negative consequences of population emigration are numerous, from demographic losses, loss of working age population to the occurrence of depopulation and biological extinguishing of households.

\begin{tabular}{|c|c|c|c|c|c|c|c|c|c|}
\hline $\begin{array}{l}\text { Cities in the } \\
\text { Republic of } \\
\text { Srpska }\end{array}$ & Total & $\begin{array}{c}\text { From } \\
\text { FBiH }\end{array}$ & $\begin{array}{c}\text { From } \\
\text { Brčko }\end{array}$ & $\begin{array}{c}\text { From } \\
\text { RS }\end{array}$ & Total & $\begin{array}{c}\text { Emigrants } \\
\text { To } \\
\text { FBiH }\end{array}$ & $\begin{array}{c}\text { To } \\
\text { Brčko }\end{array}$ & $\begin{array}{c}\text { To } \\
\text { RS }\end{array}$ & $\begin{array}{c}\text { Migration } \\
\text { balance }\end{array}$ \\
\hline Banjaluka & 20,344 & 4,619 & 283 & 13,634 & 11,019 & 3,143 & 120 & 7,756 & 9,325 \\
\hline Bijeljina & 10,531 & 2,648 & 1,545 & 6,338 & 4,336 & 1,562 & 586 & 2,188 & 6,195 \\
\hline Gradiska & 2,629 & 715 & 29 & 1.885 & 2,551 & 482 & 30 & 1,829 & 78 \\
\hline Prijedor & 4,830 & 2,687 & 30 & 2,113 & 4,593 & 1,884 & 29 & 2,680 & 237 \\
\hline Doboj & 5,540 & 2,993 & 130 & 2,417 & 11,199 & 2,857 & 110 & 8,232 & $-5,659$ \\
\hline I. Sarajevo & 12,306 & 4,989 & 79 & 7,238 & 8,337 & 2,450 & 41 & 5,846 & 3,969 \\
\hline Trebinje & 2,569 & 1,154 & 12 & 1,403 & 1,937 & 830 & 8 & 1,099 & 632 \\
\hline Zvornik & 4,297 & 2,288 & 110 & 1,899 & 5,811 & 3,253 & 117 & 2,441 & $-1,514$ \\
\hline Total & 63,046 & 22,093 & 2,218 & 36,927 & 49,783 & 16,461 & 1,041 & 32,071 & 13,263 \\
\hline
\end{tabular}

Table 4 Internal migrations of population in the cities of the Republic of Srpska, in the period from 2007 to 2016.

Source: (Marinković, Majić,2018, Page 314-315).

Due to positive migration balance, population in the cities of the Republic of Srpska increased for 13,263 persons (Table 4).

Positive migration balance shows that some cities are in the process of suburbanization, and the immigrant population is mostly from rural areas of the Republic.

Banja Luka, Bijeljina and Istočno Sarajevo had a positive balance of internal migration in every year. These are the cities with the highest number of immigrants $(43,181)$, which is $68.6 \%$ of the total number of immigrants in urban areas, and the following cities have smaller number of immigrants: Doboj 8.7\%, Prijedor 7.6\%, Zvornik 6.8\%, Gradiška 4.1\% and Trebinje 4\% (Table 4).

In all cities of the Republic of Srpska, the smallest immigration factor was in 2016 (8.2 $\%)$ and the highest in 2009 (11.1\%). It should be emphasized that the average immigration factor in the period from 2007 to 2014 in the cities of the Republic was $9.7 \%$, while the lowest immigration factor in 2015 and 2016 was $8.5 \%$ (Table 5).

In the mentioned period, the average factor of emigration in the cities of the Republic was $7.8 \%$. The highest emigration factor is in 2015 and 2016 and amounts $10.5 \%$, when the immigration factor is also the lowest, which results in a negative migration balance, which in 2015 is $-1.6 \%$ and in $2016-2.8 \%$ (Table 5).

Considering emigration and immigration, there are differences in the cities of the Republic. In the period 2007-2016, the largest population immigration occurs in Banja Luka, which is the most developed city of the Republic, with the highest number of immigrants from the surrounding rural areas. Istočno Sarajevo is at the second place, where most people migrated in the post-war period (1992-1995). In the same period, the city of Doboj has the most pronounced emigration of the population (Table 4). 


\begin{tabular}{|l|c|c|c|c|c|c|c|c|c|c|}
\hline $\begin{array}{l}\text { Cities in the } \\
\text { RS }\end{array}$ & $\mathbf{2 0 0 7}$ & $\mathbf{2 0 0 8}$ & $\mathbf{2 0 0 9}$ & $\mathbf{2 0 1 0}$ & $\mathbf{2 0 1 1}$ & $\mathbf{2 0 1 2}$ & $\mathbf{2 0 1 3}$ & $\mathbf{2 0 1 4}$ & $\mathbf{2 0 1 5}$ & $\mathbf{2 0 1 6}$ \\
\hline Banjaluka & 909 & 1,038 & 1,206 & 1,161 & 921 & 844 & 768 & 925 & 919 & 634 \\
\hline Bijeljina & 647 & 667 & 700 & 772 & 690 & 556 & 660 & 674 & 402 & 427 \\
\hline Gradiska & 48 & -19 & 23 & 23 & 19 & -31 & 4 & -24 & 29 & 6 \\
\hline Prijedor & 85 & -70 & 25 & -12 & -22 & 10 & 63 & 67 & 51 & 40 \\
\hline Doboj & -1 & 54 & 43 & 57 & 10 & 2 & -34 & 14 & -2.663 & $-3,141$ \\
\hline I. Sarajevo & 495 & 559 & 469 & 468 & 297 & 318 & 392 & 385 & 241 & 345 \\
\hline Trebinje & 119 & 41 & 71 & 32 & 40 & -49 & 99 & 110 & 110 & 59 \\
\hline Zvornik & -528 & -216 & -84 & -121 & -256 & -115 & -16 & -49 & -77 & -52 \\
\hline Total & 1,774 & 2,054 & 2,453 & 2,380 & 1,699 & 1,535 & 1,936 & 2,102 & -988 & $-1,682$ \\
\hline
\end{tabular}

Table 5 Internal migration balance in cities of the Republic of Srpska, in the period from 2007 to 2016.

Source:

http://rzs.rs.ba/static/uploads/bilteni/gradovi_i_opstine republike_srpske/2018/Gradovi_I_Opstine_Republike_S rpske 2018 WEB.pdf.

http://www.rzs.rs.ba/static/uploads/bilteni/popis/migracije/Rezultati_Popisa_2013 Migracije_WEB.pdf

According to census from 2013, there are 180,053 inhabitants in Banjaluka, of which $75 \%$ in in close urban area (Table 1). The process of suburbanization, in migration, is noticeable in peri-urban settlements in the period from 1991-2013 record population growth: in Kuljani for $70 \%$, in Priječani for $58 \%$ and in Šargovac for $57 \%$. The settlements are within $15 \mathrm{~km}$ of the city centre and belong to the marginal zone of the urban area. In the observed period, the city has a constant immigration of new residents and a positive migration balance. The migration factor ranged from $10.9 \%$ in 2007 to $8.7 \%$ in 2016. In Banja Luka, population immigration is more intense than emigration. In the period from 2007 to 2016, in relation to the total population, there were $11.2 \%$ of immigrants and $6.1 \%$ of emigrants, which is a condition of the suburbanisation process. The migration factor of emigration ranged from $7.0 \%$ in 2007 to $11.3 \%$ in 2016 .
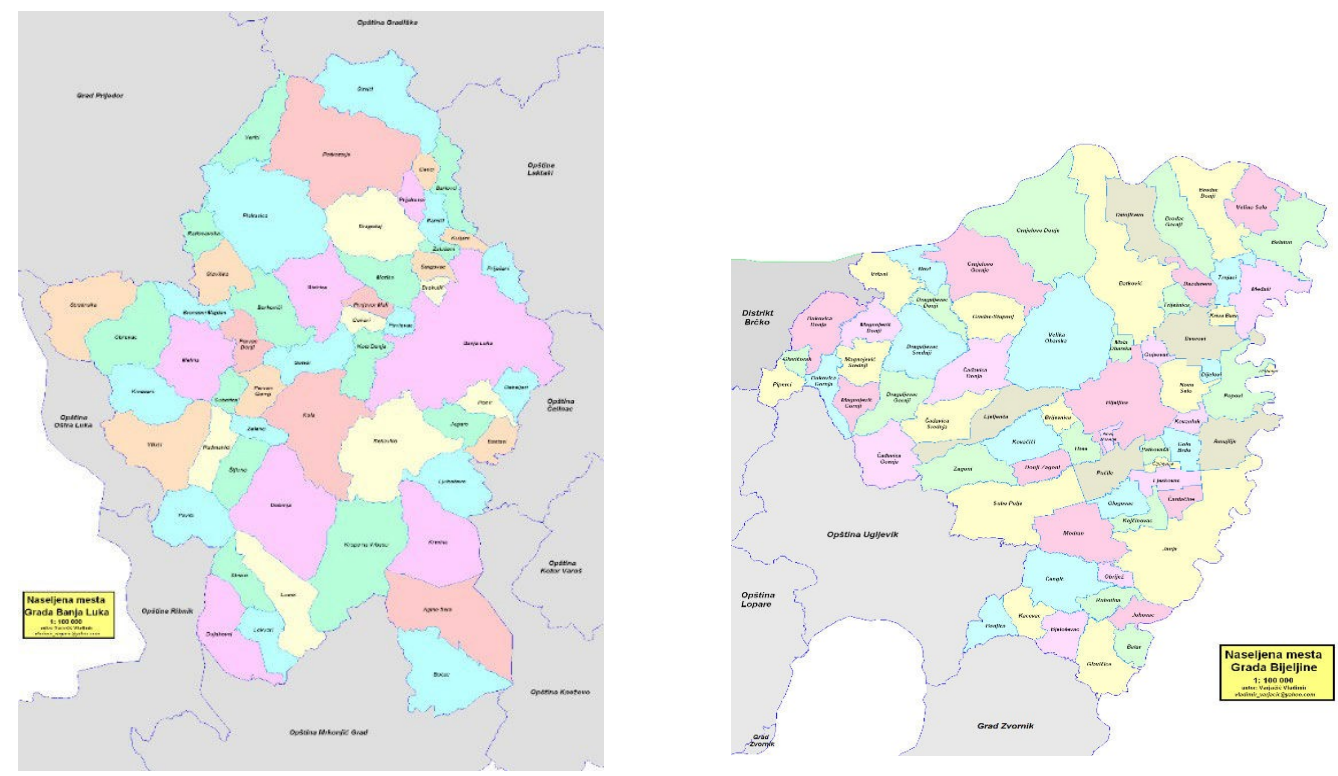

Fig.5 and $6 \mathrm{~N}$ e t w o r k of settlements of the cities of Banja Luka and Bijeljina.

Source: Varja at srpski Wikipedia - Cartographic basis: Republic Administration for Geodetic and Property Affairs of the Republic of Srpska, CC BY $3.0 \mathrm{rs,} \mathrm{https://commons.wikimedia.org/w/index.php?} \mathrm{curid=52739758.}$ https://commons. wikimedia.org/w/index.php? curid=52740087. 
Similar migration tendencies can be observed in Bijeljina. In relation to Banja Luka, in the city of Bijeljina, the largest number of the population lives in the marginal zone of the urban area. In 2013, there were 39.5\% inhabitants in close urban area (Table 1). In the period from 2007 to $2016,10,531$ new inhabitants moved to the city. The migration factor has changed from $12.4 \%$ in 2007 to $7.7 \%$ in 2016 . Three settlements in the marginal zone of the urban area of the city have the largest population increase: Patkovača for $75 \%$, Pučile for $64 \%$ and Hase for $64 \%$, within $20 \mathrm{~km}$ of the city centre.

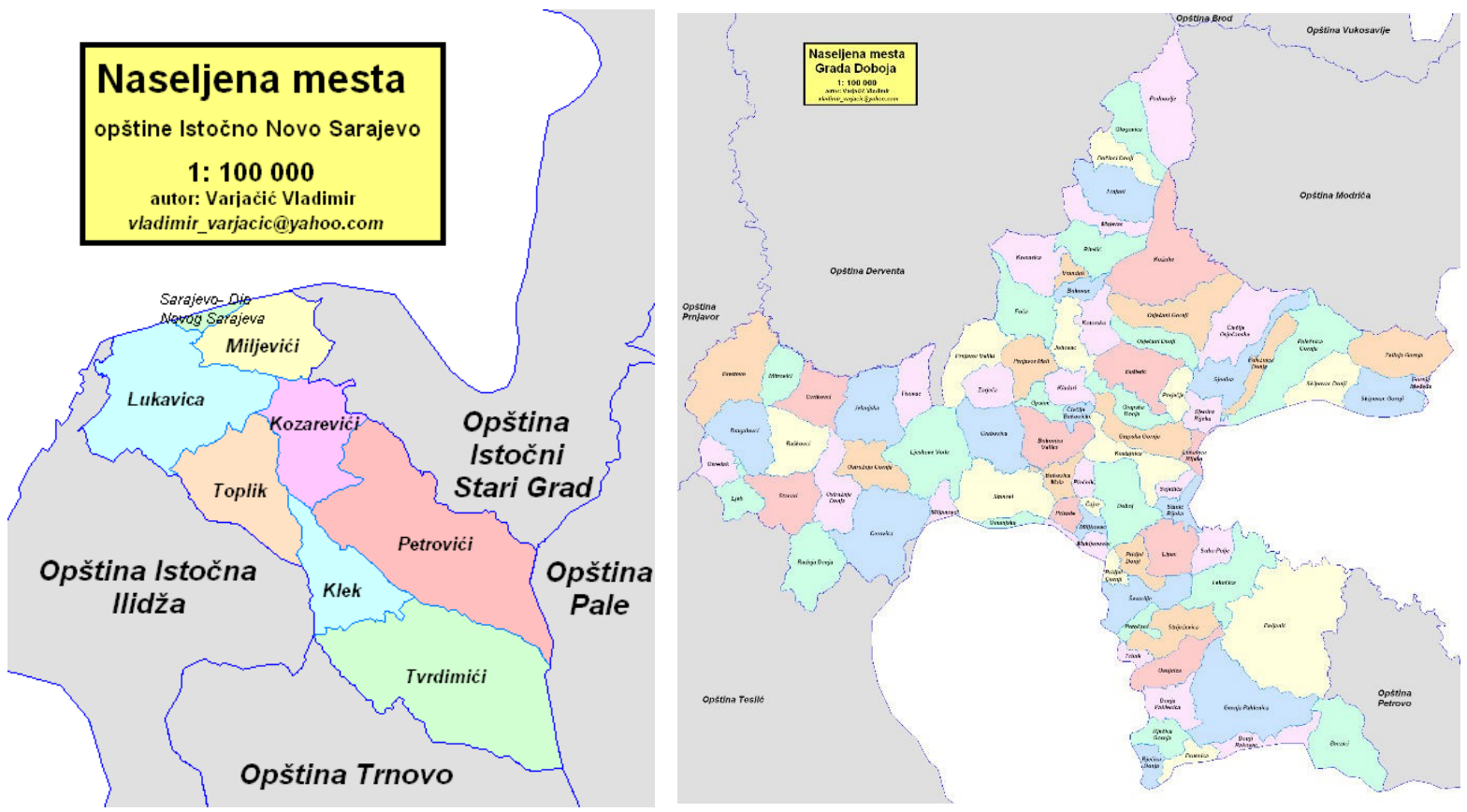

Fig. 7 and $8 \mathrm{~N} \mathrm{e} \mathrm{t} \mathrm{w} \mathrm{o} \mathrm{r} \mathrm{k} \mathrm{of} \mathrm{settlements} \mathrm{in} \mathrm{the} \mathrm{municipality} \mathrm{of} \mathrm{East} \mathrm{Novo} \mathrm{Sarajevo} \mathrm{and} \mathrm{the} \mathrm{city} \mathrm{of} \mathrm{Doboj.}$

Source: Varja at srpski Wikipedia - Cartographic basis: Republic Administration for Geodetic and Property

Affairs of the Republic of Srpska, CC BY 3.0 rs https://commons.wikimedia.org/w/index.php?curid=52793864. https://commons.wikimedia.org/w/index.php?curid=52740895.

Note: Istočno Sarajevo - Data for the City of Istočno Sarajevo include data for the municipalities of Istočno Novo Sarajevo, Istočna Ilidža, Pale, Sokolac, Tnovo and Istočni Stari Grad

12,306 new inhabitants immigrated to Istočno Sarajevo in the period from 2007 to 2016. The highest migration dynamics of immigration is observed in two periods, in the period from 2007 to 2009 , when 4,005 new inhabitants immigrated, and in the period from 2012 to 2014, when 3,802 new inhabitants immigrated. All migrants made $20.9 \%$ of the city's population. $82 \%$ of population live in the four urban settlements of the city (Istočna Ilidža, Istočno Novo Sarajevo, Sokolac and Pale) in close city area. Compared to other cities, Istočno Sarajevo has the highest number of immigrants from the $\mathrm{FBiH}(4,989)$ or $40.5 \%$. Urbanization of these settlements is emphasised, while rural settlements are losing their function. Compared to observed cities, Istočno Sarajevo is third in the number of emigrated population (Table 4). The migration factor of emigration ranged from $19.3 \%$ in 2008 to $12.6 \%$ in 2016 .

Doboj is the city in the northern part of the Republic of Srpska. 35.5\% of the population live in the urban area, while the largest number of inhabitants inhabit the marginal zone of the urban area (Table 1). Doboj is one of the cities which recorded population decrease of $28.5 \%$, compared to 1991. The process of suburbanization is poorly emphasised. In the period from 2007 to 2016, only 5,540 new inhabitants immigrated to the city. Only three settlements in the 
marginal zone of the urban area record population increases: Bukovica Velika for 45\%, Lipac for $18.3 \%$ and Kostajnica for $16 \%$. The settlements are within $15 \mathrm{~km}$ of the urban centre. In 2015 and 2016, 6,756 people left Doboj with the establishment of an administrative function in the settlement of Stanari.

Compared to other cities of the Republic, Zvornik is the only city area that has a negative value of migration balance. The city recorded increase in the number of inhabitants for 11,465 inhabitants or $17.4 \%$ compared to 1991 . Only $20.3 \%$ of the population live in close urban area, which indicates to poor functional development (Table 1). In the observed period, 4,297 inhabitants moved to the city, of which 2,288 were from the Federation of Bosnia and Herzegovina. Internal migration was most emphasised in the settlements divided by the entity line. Emigration of population is particularly pronounced in the period from 2007 to 2012 when 4,182 persons emigrated, which is $72 \%$, of the total number of emigrants in the observed period. The process of suburbanization is poorly emphasised. These changes are noticeable in three settlements in the marginal zone of urban area: Glumina, Tršić and Čelopek, which record increase of inhabitants for $20 \%$ compared to 1991 .
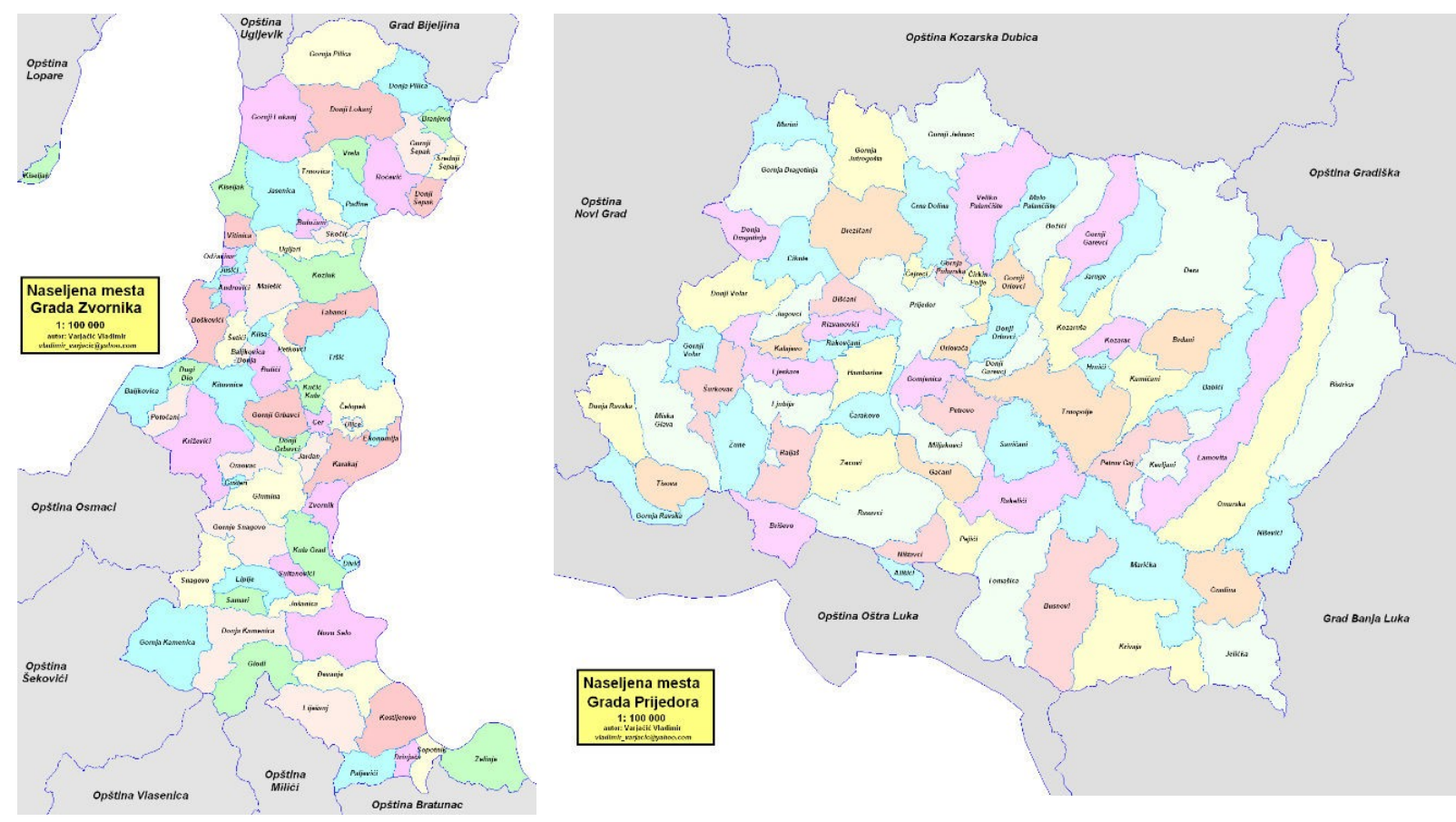

Fig.9 and 10 Network of settlements of the cities of Zvornik and Prijedo.

Source: Varja at srpski Wikipedia -Cartographic basis: Republic Administration for Geodetic and Property Affairs of the Republic of Srpska, CC BY 3.0 rs https://commons.wikimedia.org/w/index.php?curid=52817021. https://commons.wikimedia.org/w/index.php? curid=52815622.

In observed period from 2007 to 2016, Prijedor did not have positive values of the migration balance on a continuous basis. Negative values of the migration balance are recorded in 2008, 2010 and 2011. In the nine-year period, 4,830 new persons immigrated to the marginal zone of urban area. Among all studied areas, Prijedor ranks last with Gradiška and Trebinje, with the lowest number of immigrants in terms of size, while per 1000 inhabitants, the immigration process amounted around $6.7 \%$ in 2007, and up to $4.6 \%$ in 2016 . Only four settlements the marginal zone of urban area record population growth: Orlovača for $62 \%$, Donji 
Orlovci for $60.6 \%$, Čirkin Polje for $20 \%$ and Gornji Orlovci for $8.3 \%$. Above mentioned settlements are covered with suburbanization.

Compared to other cities, in the period from 2007 to 2016, Gradiška had poorly emphasised migration. The city recorded 2,629 new residents, mostly from the surrounding rural areas. Negative values of the migration balance were in 2008, 2012 and 2014. Compared to other observed cities, in Gradiška, the immigration of new inhabitants shows a decreasing trend in relation to emigration. Three settlements were covered by suburbanization in the marginal zone of urban area: Bok Jankovac, with increase in population of 35\%, Koznica 46\% and Brestovčina $65 \%$, within $10 \mathrm{~km}$ of the urban centre.

The last of the observed cities is Trebinje, in the southern part of Republika Srpska. The city is experiencing permanent population emigration, while the migration balance has been reduced from $17.3 \%$ in 2007 to $13.4 \%$ in 2016. In the period from 2013 to 2016, population emigration is decreasing. Trebinje got 977 new residents in this period, an average of 244 people per year. Suburbanization is visible in the settlement of Pridvorci. In the the marginal zone of urban area, the settlement is developing functions and, compared to 1991, it recorded increase in population number for $34 \%$.
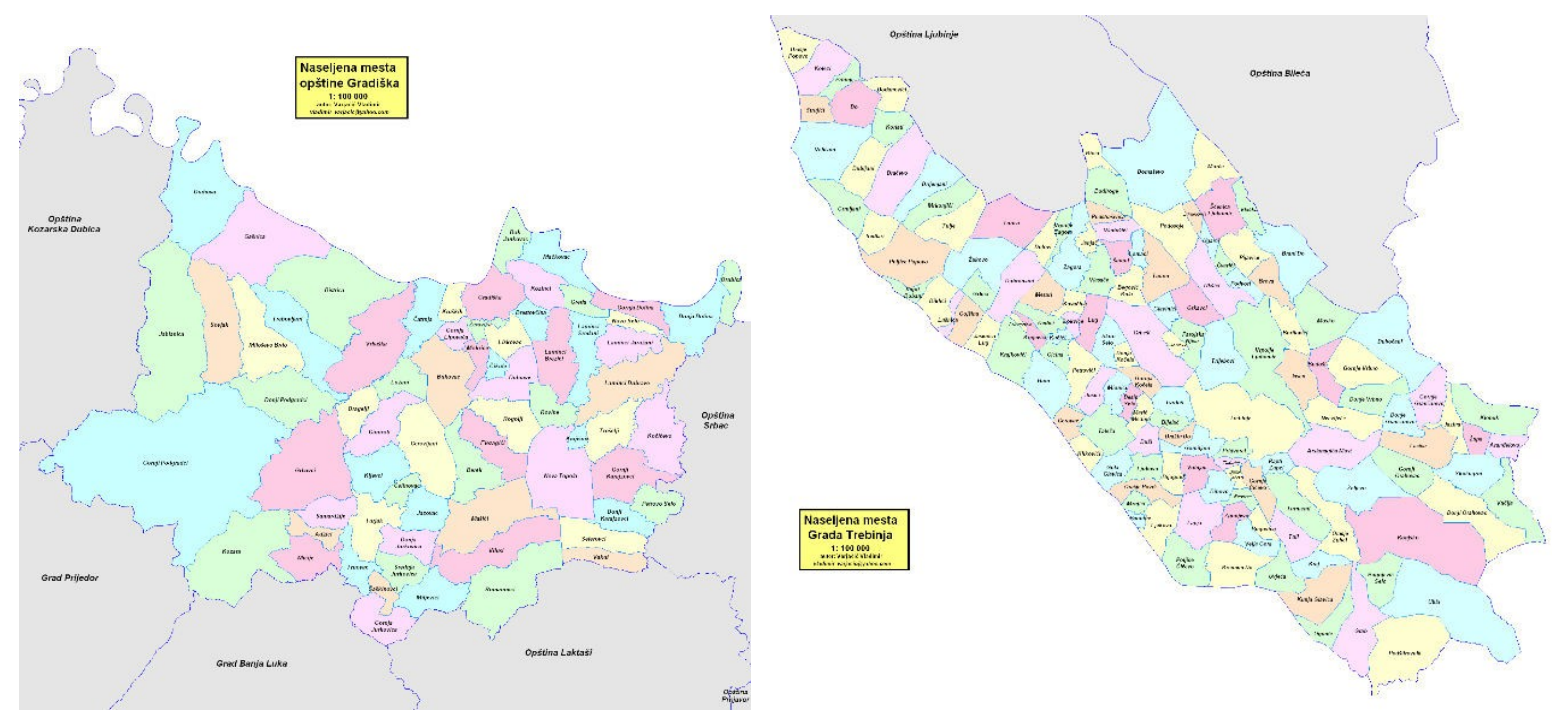

Fig.11 and 12 Network of settlements of the cities of Gradiška and Trebinje. Source: Varja at srpski Wikipedia - Cartographic basis: Republic Administration for Geodetic and Property Affairs of the Republic of Srpska, CC BY 3.0 rs https://commons.wikimedia.org/w/index.php?curid=52741138.

https://commons.wikimedia.org/w/index.php?curid=52816423.

\section{Conclusion}

Internal migrations in the cities of the Republic of Srpska contribute to the increase in population in marginal zone of urban area. The directions and tendencies of migration show that the observed cities are subject to suburbanization, which is confirmed by their spatial and functional expansion. Changes in spatial distribution of population integrate migration, as well as its direction. Suburban settlements are identified in urban systems, which represent new areas of population immigration from rural areas and other areas of the $\mathrm{FBiH}$.

Demographic processes in the cities of the Republic of Srpska take place through complex processes of depopulation, de-ruralisation, issues of biological characteristics, issues of uneven spatial distribution of the population, and the like. 
All cities of the Republic, except Doboj and Zvornik, record increased immigration and thus a positive value of the migration balance. The highest number of immigrants is recorded in Banja Luka and Bijeljina, with an average of 1,543 persons per year, and the lowest number of immigrants is in Gradiška and Trebinje, with an average of 259 persons per year.

Suburban areas located in the area of influence of major cities of the Republic have become attractive for immigration. Banjaluka and Bijeljinas were first exposed to suburbanization, then Istočno Sarajevo and Prijedor. Compared to these cities, the process is less visible in other cities of the Republic because of complex sociopolitical changes in the last decade of the $20^{\text {th }}$ century.

New residents of the cities, who emigrated from rural areas of the Republic and other areas of the $\mathrm{FBiH}$, have influenced population growth in urban areas, while their share is $59 \%$ to $79 \%$ compared to the natives.

Population growth in suburban settlements causes urban sprawl. Functions are being developed, with particular emphasis on housing function, land conversion and development of local entrepreneurship. Also, there is a need for greater financial investment in physical and social infrastructure, in terms of improving the quality of life and work in suburban settlements. In major cities, Banja Luka and Bijeljina, settlements in the marginal zone of the urban area are strongly influenced by city centres, such as, for example, settlements in suburban area of Banjaluka (Kuljani, Priječani and Šargovac) and settlements in suburban area of Bijeljina (Patkovača, Pučile and Hase). The settlements are located within $20 \mathrm{~km}$ from the city centre, with good traffic connections and relative proximity (20 to 40 minutes travel).

Most of the immigrants in urban areas are from the surrounding rural areas of the Republic, about $58.5 \%$, which is why rural areas face depopulation and lose their basic function. All options for including peripheral rural areas in future urban and rural development planning activities must be taken into consideration, to improve their attractiveness and functional development.

\section{References}

Bašić, K. (2005). Polarization of population development in city region of Zagreb. Problems of regional development of Croatia and neighbouring countries, Croatian Geographic Society, Zagreb, Page 229-236.

Bobić, M., Vesković Anđelković, M., Kokotović Kanazir V. (2016). Study on external and internal migration of Serbian citizens with special focus on young people, International Organization for Migrations, Belgrade.

Census of Population, Households, Dwellings and Farms 1991. (1991). Republic Institute of Statistics of the Federal Republic of Bosnia and Herzegovina, Sarajevo.

Census of Population, Households, Dwellings in the Republic of Srpska in 2013. (2017).

Republic Institute of Statistics of the Republic of Srpska, Banja Luka. Conference proceedings, (2011). Third Congress of Serbian Geographers, with International Participation, Gnjato R.(editor), Geographic Society of the Republic of Srpska, Faculty of Natural Sciences and Mathematics, Banjaluka. 
Conference proceedings, (2016). Šabić, D., Faculty of Geography, University of Belgrade, Volume 64.

Fürst-Bjeliš, B. (1996). Zagreb - periodization of city agglomeration development. Geographical Bulletin, Vol. 58, Page 89-96, Zagreb.

Klempić Bogadi, S. (2008). Demogeographic aspects of suburbanization of Croatia example of agglomeration of Rijeka. Doctoral thesis, University of Zagreb, Department of Geography at the Faculty of Natural Sciences and Mathematics, Zagreb.

Lukić, Tanović, M., Marinković, D. (2018). Urban and rural settlements in the City of Istočno Sarajevo, Gazette, Volume 22, Geographic Society of the Republic of Srpska, Banjaluka, Page 49-60. DOI 10.7251/HER2218049L

Mandić, M. (2013). Urban development characteristics of Banjaluka, Modern spatial- functional transformation of the city, Monography, Geographic Society of the Republic of Srpska, Banja Luka.

Marijanac, Z. (2012). Demographic reality of the Republic of Srpska 1992-2012, Conference proceedings, Geographic Society of the Republic of Srpska, Banja Luka.

Marinković, D. (2005). Demographic problems of the refugee process in the Republic of

Srpska, Monography, Geographic Society of the Republic of Srpska, Banja Luka.

Marinković, D., Majić, A. (2018). Population of the Republic of Srpska: demographic factors and indicators, Monograph, University of Banjaluka, Banja Luka.

Nejašmić, I. (1992). Basic features of internal migration of Croatian population 18801981.

Vol. 8, No. 2, Institute for Migration and Ethnic Studies, University of Zagreb, Original scientific paper. Zagreb. https://hrcak.srce.hr/127291

Nikitović, V. (2015). The population of Serbia at the beginning of the 21st century, Republic

Institit for Statistics, Belgrade.

Nodal-functional regionalization of the Republic of Srpska, project implemented by

Government of the Republic of Srpska, the Ministry of Science and

Technology and the Faculty of Science, 2008

Pejnović ,D., Buzjak, N., Bočić, N., Lukić, A., Prelogović, V., Šulc, I. (2015). Analysis and

evaluation of development potentials and restrictions of the suburban and rural areas of the City of Zagreb, University of Zagreb, City Office for Strategic Planning and Development of the City, Zagreb.

Pašalić, S., Marijanac, Z., Ěurđev, B., Marinković, D., Živković, M., Vuković , J. (2006).

Demographic development and population policy of the Republic of Srpska,

Scientific study, Mladost, Bijeljina.

Raos, V. (2010). Territoriality policies in BiH, Center for Political Science Research, Zagreb, 
https://hrcak.srce.hr/102754

Republic Institute of Statistics of the Republic of Srpska. (2017). Banja Luka:

Demographic statistics 4, 10,11, 15 and 20, Statistical newsletters, Banjaluka.

Špirić, N., Marijanac, Z. (1999). Population of the Republic of Srpska: development, perspective, refugees and displaced persons, population policy. Scientific study, University of Banjaluka, Banja Luka.

The Law on Territorial Organization and Local Self-Government of the Republic of Srpska, Official Gazette of the Republic of Srpska, number: 11/94, 6/95, 26/95, 15/96, 17/96, 19/96, 6/97, 103/05, 69/09, 70/12;

The Law on the City of Zvornik, Official Gazette of the Republic of Srpska, number: $83 / 14$,

$$
106 / 15 ; 1
$$

The Law on the City of Gradiska, Official Gazette of the Republic of Srpska, number: $26 / 19$

The Law on the City of Istocno Sarajevo, Official Gazette of the Republic of Srpska, number: $25 / 93,8 / 96,27 / 96$ and 33/97, 85/03, 01/05

The Law on the Establishment of the Municipality of Stanari, Official Gazette of the Republicb Srpska, number: 83/14.

The Law on the City, other places:

http://rzs.rs.ba/static/uploads/bilteni/gradovi_i_opstine_republike_srpske/2018/

Gradovi_I_Op stine_Republike_Srpske_2018_WEB.pdf

http://www.rzs.rs.ba/static/uploads/bilteni/popis/migracije/Rezultati_Popisa_20

13 Migracije WEB.pdf

https://commons.wikimedia.org/w/index.php?curid $=6393512$ 